Apidologie, 1984, 15 (1), 75-82.

\title{
PLECTRANTHUS AS FORAGE FOR APIS CERANA INDICA F. AND APIS MELLIFERA L.
}

\author{
J.K. GUPTA, R.C. MISHRA and JITENDER KUMAR \\ Department of Entomology-Apiculture, Himachal Pradesh Agriculture University, \\ Natui-Solan, I73230, H.P. India
}

\begin{abstract}
SUMMARY
The activity of bee foragers (A.c. indica and $A$. mellifera) was recorded on the flowers of Plectranthus rugosus and at hive entrances during different day light hours. A.c. indica foragers worked for longer hours than A. mellifera. A single A.c. indica forager visited 17.5 and 25.0 flowers per minute in the morning and afternoon whereas, $A$. mellifera visited 25.8 and 33.6 flowers per minute during the same hours. For collecting a nectar load each forager of A.c. indica and $A$. mellifera visited 288.2 and 358.0 flowers, respectively. The sugar concent:ation of the nectar of Plectranthus varied from $26.5 \%$ (morning hours) to $54.0 \%$ (Evening hours).
\end{abstract}

\section{INTRODUCTION}

The Himalayan state of Himachal Pradesh has highly varied agro-climatic zones with sub-tropical to temperate climates and presents an abundant variety of flora to honey bees. Plectranthus (Fam. Labiatae) commonly called «Shain» has six species and their identification is available in Flora Simlensis (Cor.LETT, 1921). Plectranthus rugosus is the common species in Himachal Pradesh. This perennial shrub grows on stony hillsides at altitude between 900 and 2400 meters above sea level (m.a.s.l.) and is gregarious in nature. It blooms from mid-August to November and is a source of surplus honey in autumn. Flowers of $P$. rugosus are about $0.4 \mathrm{~cm}$ long in small cymes forming racemes. The calyx is bellshaped and the corolla tubs is two lipped. The depleted strength of the colonies due to the rainy season rapidly recovers and attains the honey yielding strength in about a month's time. When the climatic conditions are congenial, the honey extraction can be started from mid-October and the good colonies 
can yield 6.8 to $9.0 \mathrm{kgs}$ of honey per colony from this source (SingH, 1962). In our program of evaluating important bee flora, studies on Plectranthus rugosus are reported in this communication.

\section{MATERIALS AND METHODS}

The present work was conducted during September, 1980 and November, 1982, at DuttnagarRampur (H.P.) situated at 1000 m.a.s.l. where the Department of Entomology-Apiculture, Solan has an apiary with both Apis cerana indica $F$. and $A$. mellifera $\mathbf{L}$. colonies. (The number of A.c. indica and $A$. mellifera colonies in the apiary was 15 and 20 respectively.)

To assess the competition between different foragers, hourly observations were recorded on the activity of bees and other insects on Plectranthus bloom. The counts were made on two bushes for 5-minutes each, during every hour and the means represent the number of insect visitors in the 5-minute counting period. These observations were started at 06.00 hours and continued till 18.00 hours. The averages of three days for different day light hours were calculated.

To find out the foraging rate, the number of flowers visited by A.c. indica and $A$. mellifera in one minute and the total number of flowers visited by them for a nectar load were also recorded. For this purpose, a single bee was marked and followed. For collecting data on the number of flowers visited for a nectar load, a bee coming directly from the direction of the hives was followed. Twenty bees of both species were thus followed individually and the average number of flowers visited per bee was calculated.

Floral buds were also caged to measure the amount of nectar secreted by them. For determining concentration of sugar in the nectar and the volume of nectar load, bees were caught on the blossoms and at hive entrances. They were gently pressed to squeezes out the honey sac contents to the glossa end and then spread on a hand refractometer for determining the sugar concentration. The volume of a nectar load carried by a bee was measured by standardized microcapillary tubes. The observations on $A . c$. indica and $A$. mellifera were recorded for three days at different hours $(08.30,10.00,12.00,14.00$ and 15.00 hours). Bee activity at the hive entrance was also recorded by counting the number of bees entering a hive pe: minute with a pollen or nectar load. These observations were started at 06.00 hours and continued till 18.00 hours. Such counts were made on three colonies of each A.c. indica and A. mellifera for 3 days.

\section{RESULTS AND DISCUSSION}

The activity of bees and other insects on flowers of $P$. rugosus during November, 1982 is shown in fig. 1. A.c. indica started foraging in the morning at 06.00 hours, whereas $A$. mellifera was seen only after 07.00 hours. Similarly, in the evening, A. mellifera stopped working after 17.00 hours and A.c. indica continued to forage until 18.00 hours. During these observations both species of the bees collected only nectar from the flowers of $P$. rugosus. Even though other good sources of pollen were available to bees, no other nectar sources were observed in the area. 


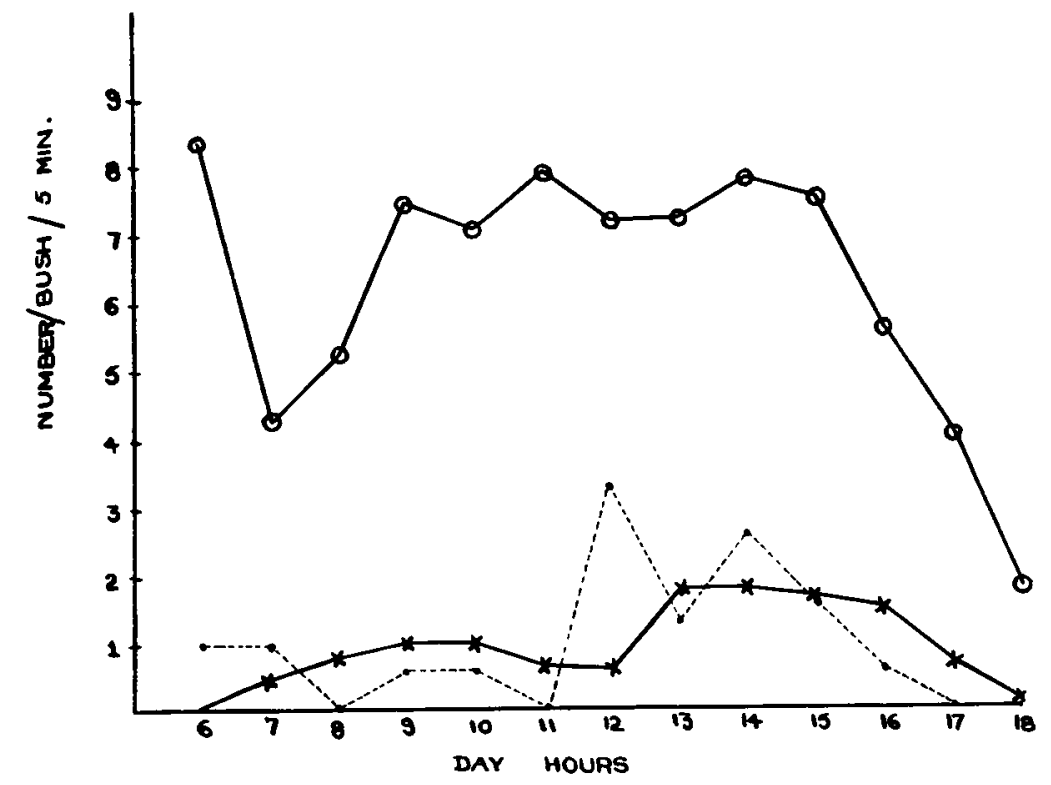

FIG. 1. - The number of A.c. indica, A. mellifera and other insects on Plectranthus bloom at different day light hours

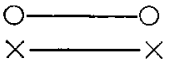

A.c. indica

A. mellifera

other insects

During September, 1980, all foragers of $A$. mellifera were observed collecting only nectar from the inflorescence. But 87.1 per cent of A.c. indica were collecting nectar and some had even pollen load by way of incidental pollen collection. The remaining 12.9 per cent of foragers were found collecting nectar only.

The activity of A.c. indica on Plectranthus remained quite high as compared with $A$. mellifera throughout the day. There was a brief decline in the number of $A$.c. indica workers foraging on the flowers from 06.00 to 07.00 hours. The number of foragers gradually increased from 07.00 to 09.00 hours and remained almost constant upto 15.00 hours and thereafter gradually decreased until 18.00 hours. The brief decline in the foragers during morning hours was perhaps due to the increase in the number of pollen collectors which was evident from 
the activity of bees at the hive entrance (fig. 2). This shift in foraging was probably the result of pollen availability during the specific day light hours from some other sources in the vicinity. However, with $A$. mellifera, the number of workers foraging on the flowers increased gradually until 14.00 hours and declined thereafter until 17.00 hours. At 18.00 hours only one A. mellifera worker was seen on the flowers during the whole period of observations.

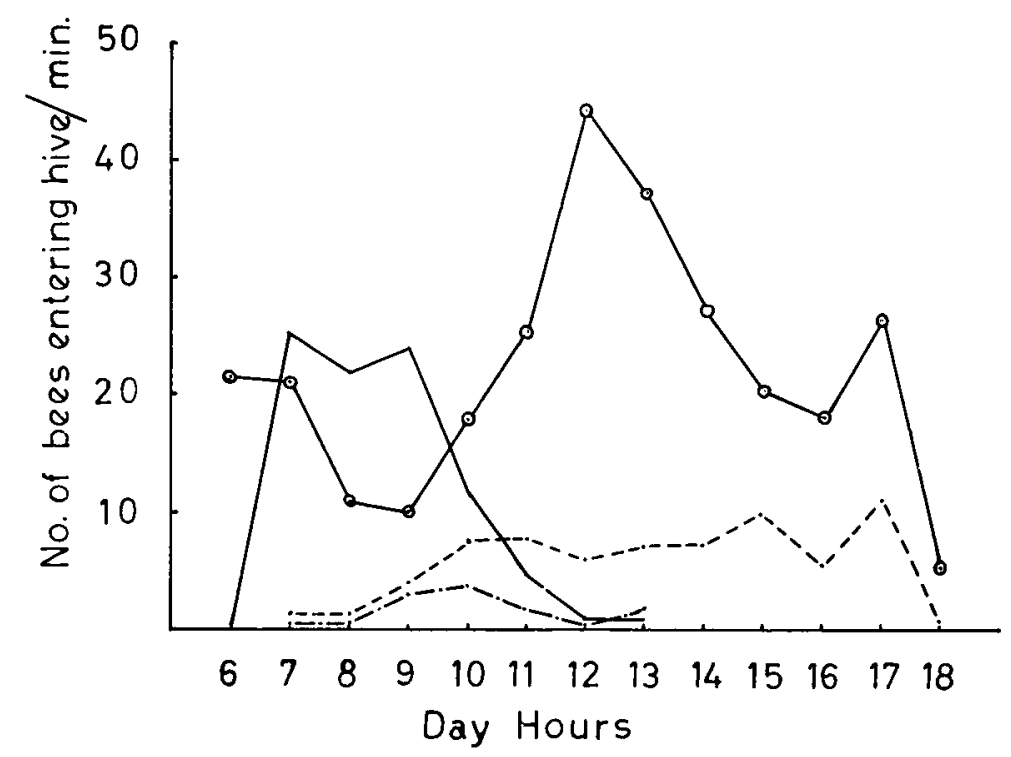

FIG. 2. - The number of incoming foragers of A.C. indica and A. mellifera with nectar and pollen loads at hive entrances at different day light hours

$\odot-\bigcirc \quad$ A.c. indica with nectar

A.c. indica with pollen

- - - . - A. mellifera with nectar

. - - A. mellifera with pollen

Other insects competing for the nectar were bumble bees and lepidopterans. The maximum activity of these insects was at 12.00 hours. There were no other insect visitors on $P$. rugosus blossoms. It was previously believed that $A$. mellifera did not forage on Plectranthus in Himachal Pradesh. But in the present observations, foraging by this exotic bee species on $P$. rugosus was confirmed. Nonutilization of this autumn source in some areas may be the result of low temperature on bee activity as has been discussed by ADLAKHA and SHARMa (1975). Stirton (1971) reported that the commonest visitors to $P$. neochilus, growing in botanical gardens, were Megachile spp., Xylocopa spp., A. mellifera and various other insects such as syrphids, Bombylids and sphingids. 
One A.c. indica bee visited an average of 17.5 and 25.0 flowers per minute in the morning (10.00 hours) and afternoon (13.15 hours), respectively, whereas A. mellifera visited 25.8 and 33.6 flowers per minute during the same hours. Thus $A$. mellifera visited more blossoms per minute than A.c. indica. This may be due to easy access on the former to the available nectar than the latter which has to spend more time for its collection. Murrell and Williams (1981) reported that A.c. indica workers foraging on Brassica compestris, spent an average of 3 seconds per floret and that this was almost constant. In our studies, A.c. indica workers spent an average of 3.4 and 2.4 seconds per floret in the morning and afternoon hours respectively, thus indicating that the time spent on $P$. rugosus flowers varied during the day. This difference in time spent per floret in the morning and evening hours may be due to the differences in the amount and concentration of nectar in the flowers.

To collect one nectar load, A.c. indica and A. mellifera foragers visited 288.2 (245 to 320 ) and 358.0 (230 to 520) flowers, respectively. The average nectar load of A.c. indica and A. mellifera was $18 \mu \mathrm{l}$ and $27 \mu l$, respectively. This indicates that $A$. mellifera is more efficient than A.c. indica in collecting nectar from $P$. rugosus. WEAVER (1965) found that a flower of hairy Vetch contained 0.02-0.08 $\mu \mathrm{l}$ of nectar with $42-65 \%$ sugar and that honey bees visited about 18-19 fiowers per minute and when 0.08 fll nectar/flower is present a bee would take 26 minutes to collect an average size load (38.48 $\mu \mathrm{l}$ of nectar). In our studies sufficient quantity of nectar could not be collected from the caged flowers to measure the total nectar secretion and its sugar concentration. Caged flowers did not wither for 7 days and possibly the flowers continue to secrete nectar for about a week or so. Sugar concentration as determined from the honey sac contents of the two bee species is shown in table 1. From the observations on sac contents while foraging and on return to hives, it is evident that there was some increase in the concentration of nectar in the honey stomach during foraging and return journey to hive. The increase in sugar concentration of honey sac contents was greater in the morning hours when bees were collecting dilute nectar. FrEE and Durrant (1966) have also reported that if the bees were given a low concentration of sucrose solution $(30 \%)$ they lost more water from their honey stomach and thereby concentrated the solution, but the higher concentrations of sucrose solution $(50-66 \%)$ were not further concentrated. It was also observed in the present study that there were small variations in the nectar concentration of honey stomach contents of $A$. mellifera and A.c. indica captured on the flowers and those entering the hives. From the data on the two species of Apis, it can be inferred that the nectar of $P$. rugosus had low sugar concentration in the morning which gradually increased in concentration through the evening and this might happen by evaporation of nectar water. 
TABL. 1. - Sugar concentration (per cent) of honey sac contents of A.c. indica and A. mellifera captured on flowers of plectranthus and at the hive entrances during different hours.

\begin{tabular}{c|c|c|c|c}
\hline \multirow{2}{*}{ Day hours } & \multicolumn{2}{|c|}{ A. mellifera } & \multicolumn{2}{|c}{ A.c. indica } \\
\cline { 2 - 4 } & Flowers & Hive & Flowers & Hive \\
\cline { 2 - 4 } 0830 & 27.0 & 33.0 & 26.5 & 39.0 \\
1000 & 36.0 & 36.9 & 38.1 & 42.0 \\
1200 & 30.0 & 31.5 & 28.2 & 28.2 \\
1400 & 48.0 & 51.0 & 49.2 & 48.6 \\
1500 & 48.9 & 48.0 & 45.0 & 54.0 \\
\hline
\end{tabular}

Bee activity of the two species as assessed by number of bees entering the hive per minute with nectar and pollen loads is represented in fig. 2 . There was intense activity at 06.00 hours in $A$.c. indica colonies $(21.6$ bees per minute with nectar load) activity was null in $A$. mellifera colonies (seen only after 07.00 hours). A.c. indica workers gathered only nectar at 06.00 hours. But from 700 to 900 hours there was a sudden increase in the number of pollen gatherers and a brief decline in the number of nectar collectors (at 08.00 hours 11 bees with nectar/minute). The maximum number of pollen gatherers was seen only during 07.00 to 09.00 hours ( 25 bees with pollen/minute). The number of pollen collectors gradually declined until at 13.00 hours and lateron no pollen gatherers were observed. After a brief decline in the number of nectar collectors during morning hours, there was a steep rise in the number reaching a peak at 12.00 hours then declining gradually until 18.00 hours. After 18.15 hours there was no activity in $A . c$. indica colonies.

Activity of $A$. mellifera was quite low as compared with $A . c$. indica with no distinct peak in activity. However, the number of pollen gatherers in this species also reached it maximum between 09.00 to 10.00 hours and no pollen collector was seen after 13.00 hours.

Received for publication in July 1983. Accepted for publication in March 1984.

\section{RESUME}

PLECTRANTHUS, SOURCE DE MIELLEE POUR APIS CERANA INDICA F. ET APIS MELLIFERA L.

Les études ont été menées à Duttnagar-Rampur H.P. (Inde) à $1000 \mathrm{~m}$ d'altitude, où le département d'Entomologie-Apiculture possède un rucher composé à la fois d'Apis cerana indica et d'Apis mellifera. 
On a enregistré toutes les heures pendant 5 minutes, de $6 \mathrm{~h}$ à $18 \mathrm{~h}$, l'activité de butinage des insectes sur Plectranthus rugosus en fleurs. Le taux de butinage (nombre de fleurs visitées par les abeilles en une minute) des deux espèces d'abeilles et le nombre de fleurs visitées par elles pour une charge de nectar ont été relevés. Afin de déterminer la concentration en sucres du nectar, à l'aide d'un réfractomètre à main, et le volume de la charge de nectar, au moyen de microcapillaires standardisés, on a capturé sur les fleurs et à l'entrée de la ruche des abeilles de chaque espèce et on les a pressées doucement pour extraire le contenu du jabot. On a également observé l'activité des abeilles à l'entrée de la ruche en comptant durant une minute toutes les heures le nombre d'abeilles qui entraient à la ruche avec une charge de pollen ou de nectar.

La figure 1 montre l'activité de divers insectes butinant les fleurs de $P$. rugosus en novembre 1982. A.c. indica se met à butiner de bonne heure à partir de $6 \mathrm{~h}$ et continue jusqu'à $18 \mathrm{~h}$, tandis que l'activité de butinage d' $A$. mellifera débute à $7 \mathrm{~h}$ et s'arrête à $17 \mathrm{~h}$. Les deux espèces ne récoltent que le nectar de $P$, rugosus. Pourtant, lors de nos observations antérieures en septembre 1980, A.c. indica récoltait à la fois le nectar et le pollen, tandis qu'A. mellifera ne butinait que le nectar. L'activité d'A.c. indica a toujours été supérieure à celle d'A. mellifera. Les autres insectes qui récoltent le nectar comprennent des bourdons et des lépidoptères.

Une butineuse d'A.c. indica visite 17,5 fleurs $/ \mathrm{mn}$ le matin à $10 \mathrm{~h}$ et 25,0 fleurs $/ \mathrm{mn}$ l'après-midi à $13 \mathrm{~h} 15$, tandis qu' $A$. mellifera visite respectivement 25,8 et 33,6 fleurs $/ \mathrm{mn}$. Pour amasser une charge de nectar, chaque butineuse d'A.c. indica et d'A. melliera visite en moyenne 288,2 fleurs (de 245 à 320 ) et 358,0 fleurs (de 230 à 520) respectivement. La charge moyenne de nectar est de $18 \mu \mathrm{l}$ chez A.c. indica et $28 \mu \mathrm{l}$ chez $A$. mellifera. La concentration en sucres. du nectar (tabl. 1) est faible le matin $(26,5 \%)$ et plus élevée l'après-midi $(54,0 \%)$.

A $6 \mathrm{~h}$ l'activité d'A.c. indica à l'entrée de la ruche est élevée $(21,6$ abeilles $/ \mathrm{mn})$, tandis que celle d'A. mellifera est nulle (fig. 2). De $7 \mathrm{~h}$ à $9 \mathrm{~h}$, l'activité de récolte de pollen par A.c. indica s'accroit soudainement $(25$ abeilles $/ \mathrm{mn})$ mais ensuite il y a une augmentation du nombre de butineuses de nectar avec un maximum à $12 \mathrm{~h}$. Le pollen provient de plantes autres que Plectranthus. L'activité d'A. mellifera est restée faible durant toute la période d'observation.

\section{ZUSAMMENFASSUNG}

\section{PLECTRANTHUS ALS BIENENWEIDE FÜR APIS CERANA INDICA F. UND APIS MELLIFERA L.}

Die Untersuchungen wurden in Duttnagar-Rampur (1 $000 \mathrm{~m}$ ü.d.M.) H.P., Indien, durchgeführt, wo das Department of Entomology-Apiculture einen Bienenstand mit Apis cerana indica und $A$. mellifera hat.

Die Sammelaktivität der Insekten wurde stündlich (von 6 bis $18 \mathrm{~h}$ ) jeweils 5 min. lang an Plectranthus rugosus-Blüten protokolliert. Die Sammelrate (Anzahl Blüten, die von den Bienen in einer Minute besucht wurden) beider Bienenarten und die Anzahl der Blüten, die auf einem Sammelflug besucht werden, wurden aufgezeichnet. Um die Zuckerkonzentration des Nektars (mit Handrefraktometer) $\mathrm{zu}$ bestimmen und das Volumen einer Nektarladung (durch Gebrauch von standardisierten Mikrokapillaren), wurden Bienen beider Arten sowohl von Blüten wie vom Stockeingang abgefangen und leicht gedrückt um den Inhalt des Honigmagens herauszupressen. Außerdem wurden stündliche Beobachtungen über die Aktivitäten der Bienen am Stockeingang durchgeführt : Die Anzahl der mit Nektar oder Pollen einfliegenden Bienen pro Minute wurde bestimmt.

Abb. 1 zeigt die Aktivität der beiden Bienenarten und von anderen Insekten an den Blüten von P. rugosus im November 1982. A.c. indica begann die Sammelaktivität um $6 \mathrm{~h}$ früh und setzte sie fort bis $18 \mathrm{~h}$, während $A$. mellifera um $7 \mathrm{~h}$ begann und nach $17 \mathrm{~h}$ aufhörte. Beide Bienenarten sammelten an $P$. rugosus nur Nektar. Gleichwohl stellten wir bei früheren Beobachtungen im September 1980 fest, daß A.c. indica beides - Nektar und Pollen - sammelte, 
während $A$. mellifera nur Nektar an $P$. rugosus sammelte. Die Aktivität von A.c. inclica war gegenüber der von $A$. mellifera immer hoch. $\mathrm{Zu}$ den übrigen Sammlerinnen gehörten Hummeln und Lepidopteren.

Einzelne A.c. indica-Sammlerinnen besuchten 17.5 Blüten pro Minute beim Nektarsammeln am Morgen $(10 \mathrm{~h})$ und 25 Blüten/Minute am Nachmittag (13.15 h) während $A$. mellifera 25,8 bzw. 33.6 Blüten pro Minute zu denselben Tageszeiten besuchten. Um eine Nektarladung zusammenzutragen, besuchten A.c. indica-Sammlerinnen durchschnittlich 288.2 (245-320) Blüten und $A$. mellifera-Sammlerinnen 358,0 (230-520) Blüten. Die durchschnittliche Nektarladung Blüten und $A$. bei A.c. indica und $27 \mu \mathrm{l}$ bei A. mellifera. Die Zuckerkonzentration des Nektars (Tab. 1) war am Morgen niedrig (26.5\%) und in den Abendstunden hoch (54\%).

Um $6 \mathrm{~h}$ war die Aktivität von A.c. indica am Stockeingang hoch (21.6 Bienen/Minute), während zu dieser Zeit bei A. mellifera keine Aktivität zu verzeichnen war (Abb. 2). Von 7 h bis $9 \mathrm{~h}$ nahm die Sammelaktivität der Pollensammlerinnen von A.c. indica zu (25 Bienen/Minute), später kam es dann zu einem steilen Anstieg an Nektarsammlerinnen mit einem Gipfel um 12 h. Pollen wurde nicht an Plectranthus sondern an anderen Quellen gesammelt. Die Aktivität von A. mellifera war während der gesamten Beobachtungsdauer niedrig.

\section{REFERENCES}

Adlakha R.L., Sharma O.P., 1975. - Apis mellifera Vs Apis indica. Glean. Bee Cult., 103 (5), 160.

Colcetr H., 1921. - Flora Simlensis. A handbook of flowering plants of Simla and neighbourhood II impression, pp. 384-386.

Free J.B., Durrant A.J., 1966. - Dilution and evaporation of honey stomach contents of honey bees at different temperatures. $J$. Apic. Res., 5 (1), 3-7.

Murrell D.C., Williams T. Nash, 1981. - Nectar secretion by « Toria» and foraging behaviour of three Apis spp. J. Apic. Res., 20 (1), 34-38.

Singh S., 1962. - Bee keeping in India. Indian Council of Agriculture Research, New Delhi, p. 214.

Stirton C.H., 1977. - Broad spectrum pollination of Plectranthus neochilus. Bothalia, 12 (2), 229-230.

Weaver N., 1965. - The foraging behaviour of honey bees on hairy vetch. I. Foraging methods and learning to forage. Insects Soc., 3, 537-549. 